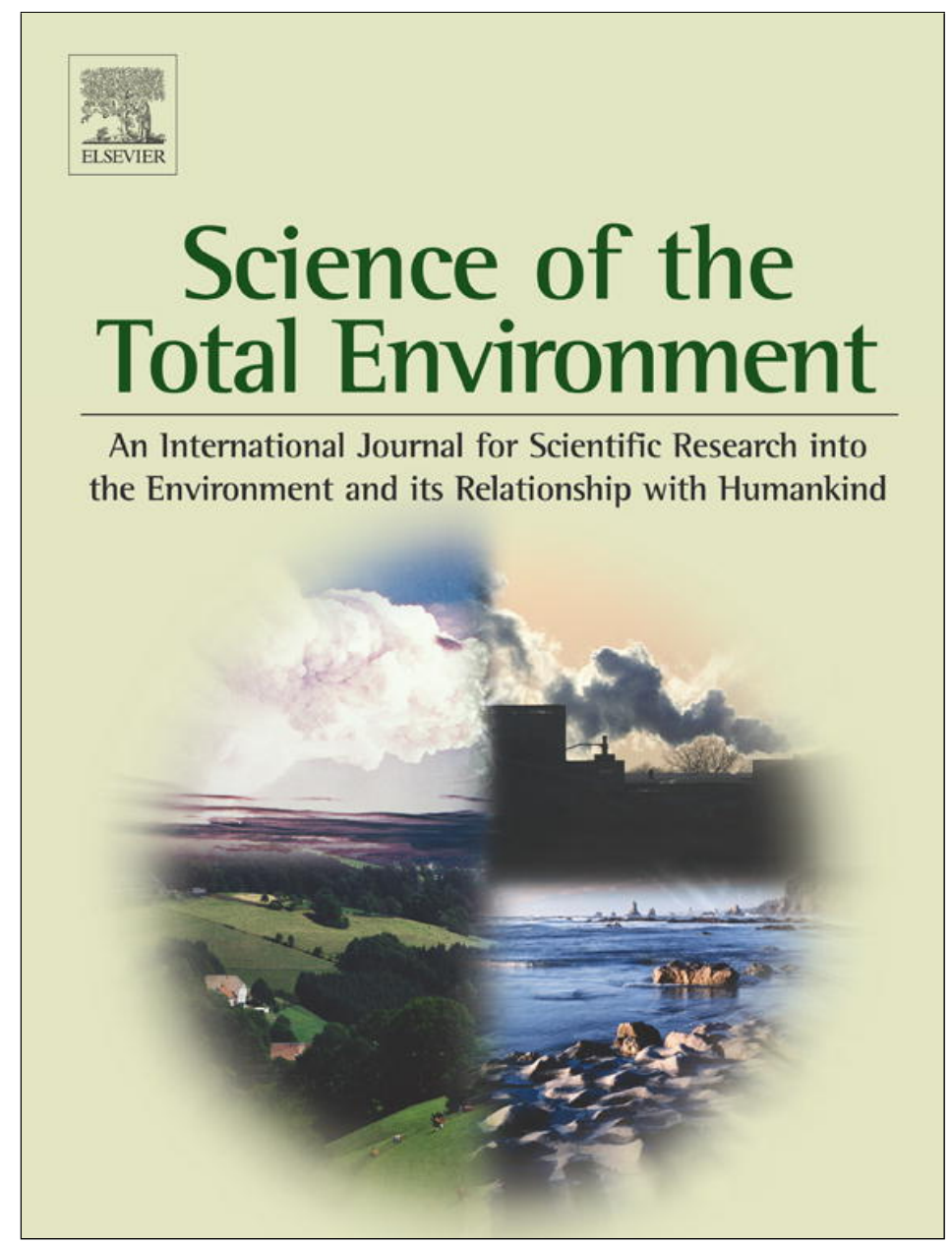

(This is a sample cover image for this issue. The actual cover is not yet available at this time.)

This article appeared in a journal published by Elsevier. The attached copy is furnished to the author for internal non-commercial research and education use, including for instruction at the authors institution and sharing with colleagues.

Other uses, including reproduction and distribution, or selling or licensing copies, or posting to personal, institutional or third party websites are prohibited.

In most cases authors are permitted to post their version of the article (e.g. in Word or Tex form) to their personal website or institutional repository. Authors requiring further information regarding Elsevier's archiving and manuscript policies are encouraged to visit: 


\title{
Fertilizer induced nitrous oxide emissions from Vertisols and Alfisols during sweet sorghum cultivation in the Indian semi-arid tropics
}

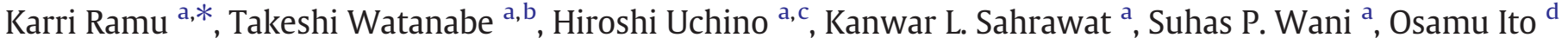 \\ a International Crops Research Institute for the Semi-Arid Tropics (ICRISAT), Patancheru, Andhra Pradesh, India \\ b Japan International Research Center for Agricultural Sciences, Ohwashi 1-1, Tsukuba, Ibaraki, Japan \\ c National Agriculture and Food Research Organization, Tohoku Agricultural Research Center, 4 Akahira, Shimo-kuriyagawa, Morioka, Iwate, Japan \\ d Institute for Sustainability and Peace, United Nations University, 53-70, Jingumae 5, Shibuya-ku, Tokyo, Japan
}

\section{H I G H L I G H T S}

- First report on $\mathrm{N}_{2} \mathrm{O}$ emissions from agriculture soils in the Indian semi-arid region.

- Applied $\mathrm{N}$ lost as $\mathrm{N}_{2} \mathrm{O}$ from Alfisols and Vertisols was 0.90 and $0.32 \%$ respectively.

- $\mathrm{N}_{2} \mathrm{O}$ emissions are dependent on the soil properties.

\section{A R T I C L E I N F O}

\section{Article history:}

Received 16 June 2012

Received in revised form 31 July 2012

Accepted 1 August 2012

Available online $\mathrm{xxxx}$

\section{Keywords:}

Nitrous oxide

Sweet sorghum

Vertisols

Alfisols

Semi-arid

\begin{abstract}
A B S T R A C T
Nitrous oxide $\left(\mathrm{N}_{2} \mathrm{O}\right)$ emissions from Vertisols and Alfisols during sweet sorghum cultivation in the Indian semi-arid tropics were determined using a closed chamber technique during the rainy season (June-October) of 2010. The study included two treatments, nitrogen $(\mathrm{N})$ at a rate of $90 \mathrm{~kg} / \mathrm{ha}$ and a control without $\mathrm{N}$ fertilizer application. The $\mathrm{N}_{2} \mathrm{O}$ emissions strongly coincided with $\mathrm{N}$ fertilization and rainfall events. The cumulative $\mathrm{N}_{2} \mathrm{O}-\mathrm{N}$ emission from Alfisols was $1.81 \mathrm{~N}_{2} \mathrm{O}-\mathrm{N} \mathrm{kg} /$ ha for $90 \mathrm{~N}$ treatment and $0.15 \mathrm{~N}_{2} \mathrm{O}-\mathrm{N} \mathrm{kg} / \mathrm{ha}$ for the $0 \mathrm{~N}$ treatment. Similarly, the $\mathrm{N}_{2} \mathrm{O}-\mathrm{N}$ emission from Vertisols was $0.70 \mathrm{~N}_{2} \mathrm{O}-\mathrm{N} \mathrm{kg} / \mathrm{ha}$ for $90 \mathrm{~N}$ treatment and $0.09 \mathrm{~N}_{2} \mathrm{O}-\mathrm{N} \mathrm{kg} / \mathrm{ha}$ for the $0 \mathrm{~N}$ treatment. The mean $\mathrm{N}_{2} \mathrm{O}-\mathrm{N}$ emission factor for fertilizer induced emissions from the Alfisols was $0.90 \%$ as compared to $0.32 \%$ for Vertisols. Our results suggest that the $\mathrm{N}_{2} \mathrm{O}$ emissions are dependent on the soil properties. Therefore, the monitoring of $\mathrm{N}_{2} \mathrm{O}$ emissions from different agro-ecological regions, having different soil types, rainfall characteristics, cropping systems and crop management practices are necessary to develop comprehensive and accurate green house gas inventories.
\end{abstract}

(c) 2012 Elsevier B.V. All rights reserved.

\section{Introduction}

Nitrous oxide $\left(\mathrm{N}_{2} \mathrm{O}\right)$ is an important trace gas that causes global warming and stratospheric ozone depletion. The global atmospheric $\mathrm{N}_{2} \mathrm{O}$ concentration increased from a pre-industrial value of about $270 \mathrm{ppb}$ to $319 \mathrm{ppb}$ in 2005 (Intergovernmental Panel on Climate Change, IPCC, 2007), and this increase is thought to be due to anthropogenic emissions of greenhouse gases (GHGs). Globally, agricultural soils account for about $60 \%$ of the atmospheric $\mathrm{N}_{2} \mathrm{O}$ emissions (Mosier et al., 1998; Kroeze et al., 1999). In agricultural soils, $\mathrm{N}_{2} \mathrm{O}$ is mainly generated from mineral $\mathrm{N}$ originating from applied $\mathrm{N}$ fertilizer, mineralization of soil organic $\mathrm{N}$ and biologically fixed $\mathrm{N}_{2}$ (Freney, 1997). Among these, the application of reactive $\mathrm{N}$ in the form of synthetic fertilizers is considered a primary source of $\mathrm{N}_{2} \mathrm{O}$ emissions from agricultural soils (Mosier et al., 1998; Mosier and Kroeze, 2000). Nevertheless, $\mathrm{N}$ fertilizers are essential to face the rise in food requirements for a burgeoning human

\footnotetext{
* Corresponding author. Tel.: +914030713308.

E-mail addresses: r.karri@cgiar.org, karriramureddy@gmail.com (K. Ramu).
}

population coupled with the reduction in agricultural land. Thus, it can be anticipated that with the accelerating demand for $\mathrm{N}$ fertilizers the current trend of increasing atmospheric $\mathrm{N}_{2} \mathrm{O}$ concentrations will likely to continue over the next several decades.

In recent years, rapid changes in land-use are taking place in tropical Asia, which may cause changes in the amounts of emission of GHGs from terrestrial ecosystems. Mosier and Kroeze (2000) estimated that the $\mathrm{N}_{2} \mathrm{O}$ emissions to the atmosphere would increase about 1.4 times between 1990 and 2020, with much of this increase projected to occur in Asia. India is the second largest producer and consumer of $\mathrm{N}$ fertilizer in the world (Prasad, 2012). The Ministry of Environment and Forests (MoEF), India (2007) estimated the GHGs emissions from agriculture to be $17 \%$ of the net $\mathrm{CO}_{2}$ equivalent emissions of the total GHGs emissions.

The demand for energy in India is growing at an annual rate of $4.8 \%$ (Agoramoorthy, 2012). Biofuels are being promoted widely as a solution to rising fuel prices, growing energy demands and to cut the emissions of GHGs. Recently, there has been a lot of impetus on the use of feed stocks that are non-food grain and that can grow on marginal 
and abandoned lands. Sweet sorghum (Sorghum bicolor (L.) Moench) is one such crop that is gaining global interest as a feedstock for biofuel production as it can be grown under widely differing climatic conditions (Rao et al., 2009). Given the current interest in commercial and large-scale exploitation of sweet sorghum as a bio-ethanol crop and with the anticipated increase in $\mathrm{N}$ inputs, there is a risk that $\mathrm{N}_{2} \mathrm{O}$ emissions from high $\mathrm{N}$ applications will reduce the $\mathrm{GHG}$ advantages sought from biofuel production.

The primary objective of this study was to quantify the $\mathrm{N}$ fertilizerinduced $\mathrm{N}_{2} \mathrm{O}$ emissions during the sweet sorghum growing season. As agricultural $\mathrm{N}_{2} \mathrm{O}$ emissions are generally dependent on soil types, the study was conducted in two soil types, Alfisols (Ferric Luvisol, FAO classification; Udic Rhodustalf, USDA classification) and Vertisols (Pellic Vertisol, FAO classification; Typic Pellustert, USDA classification). Furthermore, though semi-arid and arid lands constitute a large part of the global land area and are widely used for agricultural production, there are few studies relating to $\mathrm{N}_{2} \mathrm{O}$ emissions from semi-arid agricultural soils (Barton et al., 2008, 2010; Pang et al., 2009). Thus, this study was carried out to understand the $\mathrm{N}_{2} \mathrm{O}$ fluxes from agricultural soils in semi-arid regions to assess the GHG emissions from this particular bioenergy cropping system. The study may aid in future recommendations for reducing $\mathrm{N}_{2} \mathrm{O}$ emissions from sweet sorghum farming.

\section{Materials and methods}

\subsection{Study location and description of the experiment}

The study was carried out at the farm of the International Crops Research Institute for the Semi-Arid Tropics (ICRISAT), Patancheru, India located at $17^{\circ} 53^{\prime} \mathrm{N}$ and $78^{\circ} 27^{\prime} \mathrm{E}$, at an altitude of $545 \mathrm{~m}$ above mean sea level during the rainy season of 2010 (June-October). The climate of the region is subtropical and semi-arid. The area receives an annual rainfall of $800 \mathrm{~mm}$, about $80 \%$ of which occurs from June to September. Soil properties $(0-15 \mathrm{~cm}$ depth) of the experimental fields are reported in Table 1.

The present study included two treatments, $\mathrm{N}$ at a rate of $90 \mathrm{~kg} / \mathrm{ha}$ and a control without $\mathrm{N}$ fertilizer application. The treatments were assigned as a randomized block design with three replications and each plot measured $8 \mathrm{~m}$ long and $6 \mathrm{~m}$ wide. Urea (46\% N) was applied at the rate of $90 \mathrm{~kg} \mathrm{~N} / \mathrm{ha}$ in three split doses, i.e. $15 \mathrm{~kg} \mathrm{~N} / \mathrm{ha}$ (basal), $37.5 \mathrm{~kg} \mathrm{~N} / \mathrm{ha}$ (1st top-dressing) and $37.5 \mathrm{~kg} \mathrm{~N} / \mathrm{ha}$ (2nd top-dressing) at 0,30 and 60 days after sowing (DAS). Nitrogen fertilizer was applied in splits at a depth of $5 \mathrm{~cm}$ on each side of the plant row, and covered with soil. Other nutrients (phosphorous (P): $40 \mathrm{~kg} \mathrm{P}_{2} \mathrm{O}_{5} \mathrm{ha}^{-1}$, sulfur (S): $200 \mathrm{~kg}_{\text {gypsum ha }}{ }^{-1}, \mathrm{~B}: 0.475 \mathrm{~kg} \mathrm{Bha}^{-1}, \mathrm{Zn}: 50 \mathrm{~kg} \mathrm{ZnSO}_{4} \mathrm{ha}^{-1}$ ) were incorporated into the soil at sowing of the crop. Promising sweet sorghum hybrid in India "CSH 22 SS" (Rao et al., 2009), was grown on the ridges landform $20 \mathrm{~cm}$ apart and with an inter row width of $60 \mathrm{~cm}$ with a planting density of $8.3 / \mathrm{m}^{2}$. Sowing was done on 10th June and 22nd June 2010 in Vertisols and Alfisols, respectively.

Table 1

Properties of the soils at $0-15 \mathrm{~cm}$ depth.

\begin{tabular}{lcc}
\hline & Alfisols & Vertisols \\
\hline Particle size classes & & \\
\% Coarse sand $0.2-2 \mathrm{~mm}$ & 44.1 & 12.5 \\
\% Fine sand 0.02-0.2 mm & 27.5 & 13.9 \\
\% Silt 0.002-0.02 mm & 7.1 & 22.1 \\
\% Clay $<0.002 \mathrm{~mm}$ & 21.3 & 51.5 \\
& & \\
FAO classification & Ferric Luvisol & Pellic Vertisol \\
\hline pH $\left(\mathrm{H}_{2} \mathrm{O}\right)$ & 7.8 & 8.3 \\
EC $(\mathrm{dS} / \mathrm{m})$ & 0.22 & 0.18 \\
Total N $(\mathrm{mg} / \mathrm{kg})$ & 755 & 560 \\
Organic C \% & 0.50 & 0.57 \\
\hline
\end{tabular}

\subsection{Gas sampling}

A cylindrical stainless steel chamber, $0.20 \mathrm{~m}$ in diameter and $0.16 \mathrm{~m}$ high, was used for the collection of gas samples. Two chambers were installed in each plot, one chamber was placed on the ridge and another in the furrow. Chambers were installed at least $24 \mathrm{~h}$ before sampling, and left in situ, except for when they had to be removed temporarily for carrying out farming operations. Chambers were left uncovered throughout except for during the periods when gas samples were collected. The chambers were inserted to a depth of up to $3 \mathrm{~cm}$ to ensure an airtight seal. The surface area enclosed by the chamber was $0.031 \mathrm{~m}^{2}$. Samples were collected between 08.00 and $11.00 \mathrm{AM}$, thrice weekly, following $\mathrm{N}$ fertilization when the potential for $\mathrm{N}_{2} \mathrm{O}$ emissions was higher due to the availability of $\mathrm{N}$ substrate. Sampling frequency was reduced following 2 weeks after fertilization when the emissions fell close to background levels. The sampling process consisted of manually extracting samples from the headspace of the chamber through a septum using a $25 \mathrm{ml}$ polypropylene syringe at 0,15 and $30 \mathrm{~min}$ after closure and transferring the air samples to pre-evacuated $12 \mathrm{ml}$ Exetainers vials (Labco Limited, UK) fitted with a butyl rubber stopper and a screw cap. Atmospheric samples were also collected to provide background values for $\mathrm{N}_{2} \mathrm{O}$.

\subsection{Analysis of nitrous oxide}

$\mathrm{N}_{2} \mathrm{O}$ concentrations were determined using a gas chromatograph (Shimadzu, GC-2014, Japan) equipped with a ${ }^{63} \mathrm{Ni}$ electron capture detector (ECD) and switching valves. Separation was performed using stainless-steel columns packed with 80/100 mesh Porapak-Q. The column oven, injection port and detector temperatures were set at $80{ }^{\circ} \mathrm{C}, 150{ }^{\circ} \mathrm{C}$ and $280{ }^{\circ} \mathrm{C}$, respectively. Nitrogen gas at a flow rate of $65 \mathrm{ml} / \mathrm{min}$ was used as the carrier gas. A mixture of argon (Ar) gas containing $5 \% \mathrm{CH}_{4}$ was added to the $\mathrm{N}_{2}$ carrier gas flow before the detector to increase the sensitivity of the detector. $\mathrm{N}_{2} \mathrm{O}$ fluxes were calculated from the rate of change in the concentration of $\mathrm{N}_{2} \mathrm{O}$ in the air inside the chambers during the time of sampling. This was estimated by the slope of the linear regression between concentration and time and from the ratio between chamber volume and soil surface area. Cumulative $\mathrm{N}_{2} \mathrm{O}$ fluxes were determined by linearly interpolating data points between each successive sampling event, and integrating the underlying area.

\subsection{Statistical analysis}

Statistical analysis was conducted using the SPSS software (version 12.0E, SPSS Japan). Analysis of variance (ANOVA) was performed by combined model (McIntosh, 1983). Fields (Alfisols and Vertisols), N treatments ( 0 and $90 \mathrm{~N}$ ) and position of chambers (ridges and furrows) were treated as fixed factors, and replication as a random factor.

\subsection{Ancillary measurements}

Soil samples were collected before sowing to determine physical and chemical properties of the soil. The samples from each plot were mixed, dried and sieved.

Meteorological data on mean air temperature and precipitation were obtained from the ICRISAT weather station in Patancheru, India.

\section{Results and discussion}

\subsection{Climate conditions}

The average daily maximum temperature was $30^{\circ} \mathrm{C}$, and ranged from $24{ }^{\circ} \mathrm{C}$ to $37{ }^{\circ} \mathrm{C}$ during the growing period, while the average daily minimum temperature was $23^{\circ} \mathrm{C}$ and ranged from $19{ }^{\circ} \mathrm{C}$ to 
$25{ }^{\circ} \mathrm{C}$ throughout the growing period (Fig. 1). The total rainfall received during the growing period was $941 \mathrm{~mm}$. Rainfall was well spread during the growing season and furrow irrigation was conducted only once in both the fields. The maximum amount of rainfall was received during August (Fig. 1). This resulted in many periods of high soil moisture content.

\subsection{Emissions of $\mathrm{N}_{2} \mathrm{O}-\mathrm{N}$}

Nitrous oxide emissions are episodic in nature. The application of $\mathrm{N}$ and wet soil conditions after high precipitation are usually followed by periods of high $\mathrm{N}_{2} \mathrm{O}$ emissions (Sahrawat and Keeney, 1986). In the present study, the schedule of gas sampling was planned accordingly to observe $\mathrm{N}_{2} \mathrm{O}$ emissions frequently for 2 weeks after $\mathrm{N}$ applications. Figs. 2a and 3a show the temporal variations in $\mathrm{N}_{2} \mathrm{O}$ emissions from the ridges in the Vertisol and the Alfisol fields, respectively. Similarly, Figs. $2 b$ and $3 b$ show the temporal variations in $\mathrm{N}_{2} \mathrm{O}$ emissions from the furrows in the Vertisol and the Alfisol fields, respectively. A summary of cumulative $\mathrm{N}_{2} \mathrm{O}$ fluxes from the various treatments is presented in Table 2. Analysis of variance indicated the significant effect of fertilizer $\mathrm{N}$ on cumulative $\mathrm{N}_{2} \mathrm{O}$ fluxes $(P<0.01)$. Also, there was significant field-by- $\mathrm{N}$ treatment interaction $(P<0.05)$ suggesting that $\mathrm{N}_{2} \mathrm{O}$ emissions increased with the application of fertilizer $\mathrm{N}$ in both Alfisols and Vertisols, but it increased more largely for Alfisols than for Vertisols. Results from the two study sites showed a consistent pattern in $\mathrm{N}_{2} \mathrm{O}$ emissions. As in most previous studies (Watanabe et al., 2000; Hellebrand et al., 2008; Fernández-Luqueño et al., 2009), $\mathrm{N}_{2} \mathrm{O}$ emissions were stimulated following $\mathrm{N}$ fertilization. The addition of urea significantly increased $\mathrm{N}_{2} \mathrm{O}$ emissions compared to the unfertilized plots, by providing additional substrate for nitrification and/or denitrification. A significant effect of the placement of chambers on ridges and furrows on cumulative $\mathrm{N}_{2} \mathrm{O}$ fluxes was observed $(P<0.01)$. As urea was applied only to the ridges, higher $\mathrm{N}_{2} \mathrm{O}$ emission rates just after fertilization occurred from the ridges than from furrows. Similar to the results of this study, $\mathrm{N}_{2} \mathrm{O}$ fluxes from rows planted to soybeans were significantly higher than that in between rows in the Midwest United States (Parkin and Kaspar, 2006). However, McTaggart and Smith (1996) found $\mathrm{N}_{2} \mathrm{O}$ emissions from furrows to be larger than that from the ridges though $\mathrm{N}$ was applied into the ridges. Such a phenomenon was attributed to a combination of fertilizer $\mathrm{N}$ movement from the ridges to furrows by leaching and diffusion with higher soil moisture content in the furrows.

\subsection{Emission of $\mathrm{N}_{2} \mathrm{O}-\mathrm{N}$ from Vertisols}

Immediately after the application of urea, $\mathrm{N}_{2} \mathrm{O}$ emissions were commonly elevated for the first few weeks and then declined to approach background values. Sahrawat (1984) reported that the hydrolysis of urea was rapid in the semi-arid tropical soil, almost all the urea was hydrolyzed within $24 \mathrm{~h}$ of application, at soil moisture content near field capacity and at soil temperatures of $27-37^{\circ} \mathrm{C}$. The hydrolysis of urea followed by nitrification and denitrification are the most important processes that contribute to the emission of $\mathrm{N}_{2} \mathrm{O}$ from the soil. The highest value of $\mathrm{N}_{2} \mathrm{O}$ flux for the $90 \mathrm{~kg} \mathrm{~N} /$ ha treatment was $355 \mathrm{~N}_{2} \mathrm{O}-$ $\mathrm{N} \mu \mathrm{g} / \mathrm{m}^{2} / \mathrm{h}$, which occurred after the second topdressing (Fig. 2a). After the $\mathrm{N}_{2} \mathrm{O}$ emission peaks, which were followed by second top dressing, the $\mathrm{N}_{2} \mathrm{O}$ emissions reached and stayed at the background levels until harvest of the crop. Nitrogen fertilization appeared to be the most important factor that stimulated $\mathrm{N}_{2} \mathrm{O}$ emission. The $\mathrm{N}_{2} \mathrm{O}$ emissions from the furrows were considerably less compared to that from the ridges (Fig. 2b). The cumulative $\mathrm{N}_{2} \mathrm{O}-\mathrm{N}$ emission during the cultivation of sweet sorghum was $0.70 \mathrm{~N}_{2} \mathrm{O}-\mathrm{N} \mathrm{kg}$ /ha for $90 \mathrm{~N}$ treatment and $0.09 \mathrm{~N}_{2} \mathrm{O}-\mathrm{N} \mathrm{kg} / \mathrm{ha}$ for the $0 \mathrm{~N}$ treatment.

\subsection{Emission of $\mathrm{N}_{2} \mathrm{O}-\mathrm{N}$ from Alfisols}

As in the case of the Vertisol, a similar trend in $\mathrm{N}_{2} \mathrm{O}$ emissions was observed for the Alfisol. The $\mathrm{N}_{2} \mathrm{O}$ fluxes generally increased sharply after $\mathrm{N}$-fertilizer additions before tailing off to low values, until the next fertilizer addition. The mean highest flux was $1570 \mathrm{~N}_{2} \mathrm{O}-\mathrm{N} \mu \mathrm{g} / \mathrm{m}^{2} / \mathrm{h}$, observed after the second top-dressing (Fig. 3a). The magnitude of $\mathrm{N}_{2} \mathrm{O}$ emission from soil depends not only on the availability of $\mathrm{N}$ but also on other factors such as soil temperature, soil aeration, availability of carbohydrates, $\mathrm{pH}$ and soil water content (Sahrawat and Keeney, 1986). Because of the frequent rainfall throughout the growing season, it resulted in many periods of high soil moisture content, which favored the production of $\mathrm{N}_{2} \mathrm{O}$. The large peaks of $\mathrm{N}_{2} \mathrm{O}$ flux were observed in response to rainfall events after the application of urea (Figs. 1 and 3a). The high $\mathrm{N}_{2} \mathrm{O}$ fluxes might have been caused by active nitrification after $\mathrm{N}$ application under high moisture condition. As the $\mathrm{N}_{2} \mathrm{O}$ emissions were seen soon after the application of urea, it is suspected that nitrification was the dominant processes in the emissions of $\mathrm{N}_{2} \mathrm{O}$ in this study. The $\mathrm{N}_{2} \mathrm{O}$ emissions from the furrows were comparable to that from the unfertilized plots (Fig. 3b). The cumulative $\mathrm{N}_{2} \mathrm{O}-\mathrm{N}$ emission during the sweet sorghum cultivation

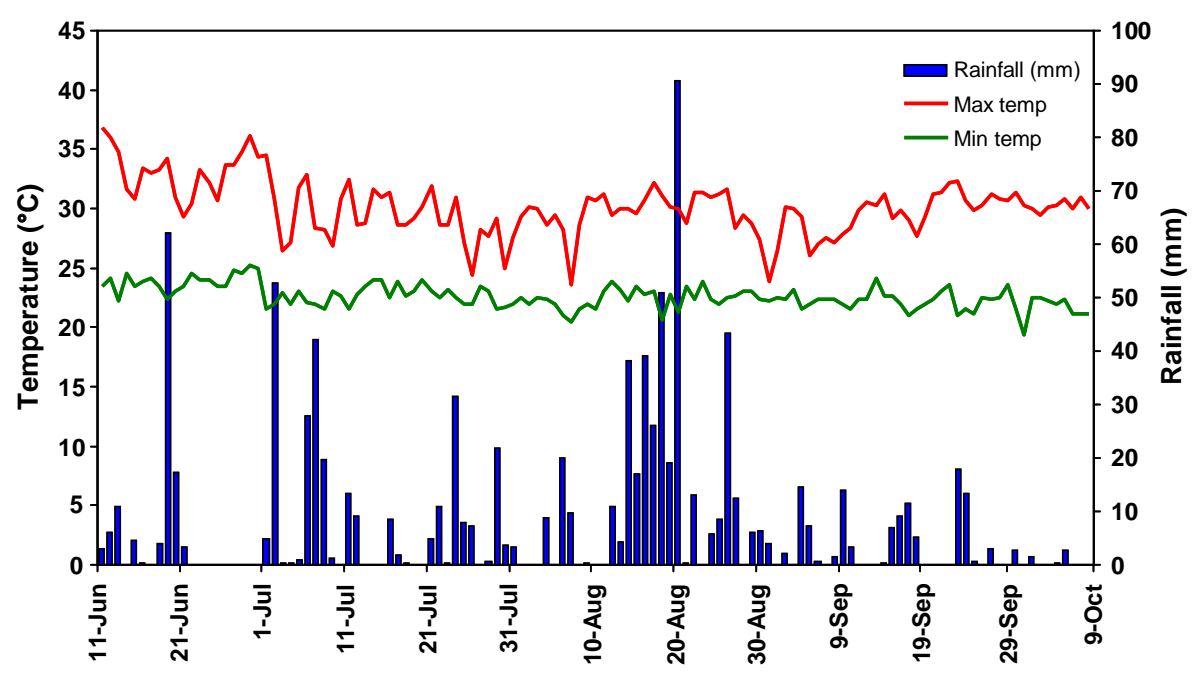

Fig. 1. Variation in temperature and rainfall during the Kharif season 2010. 

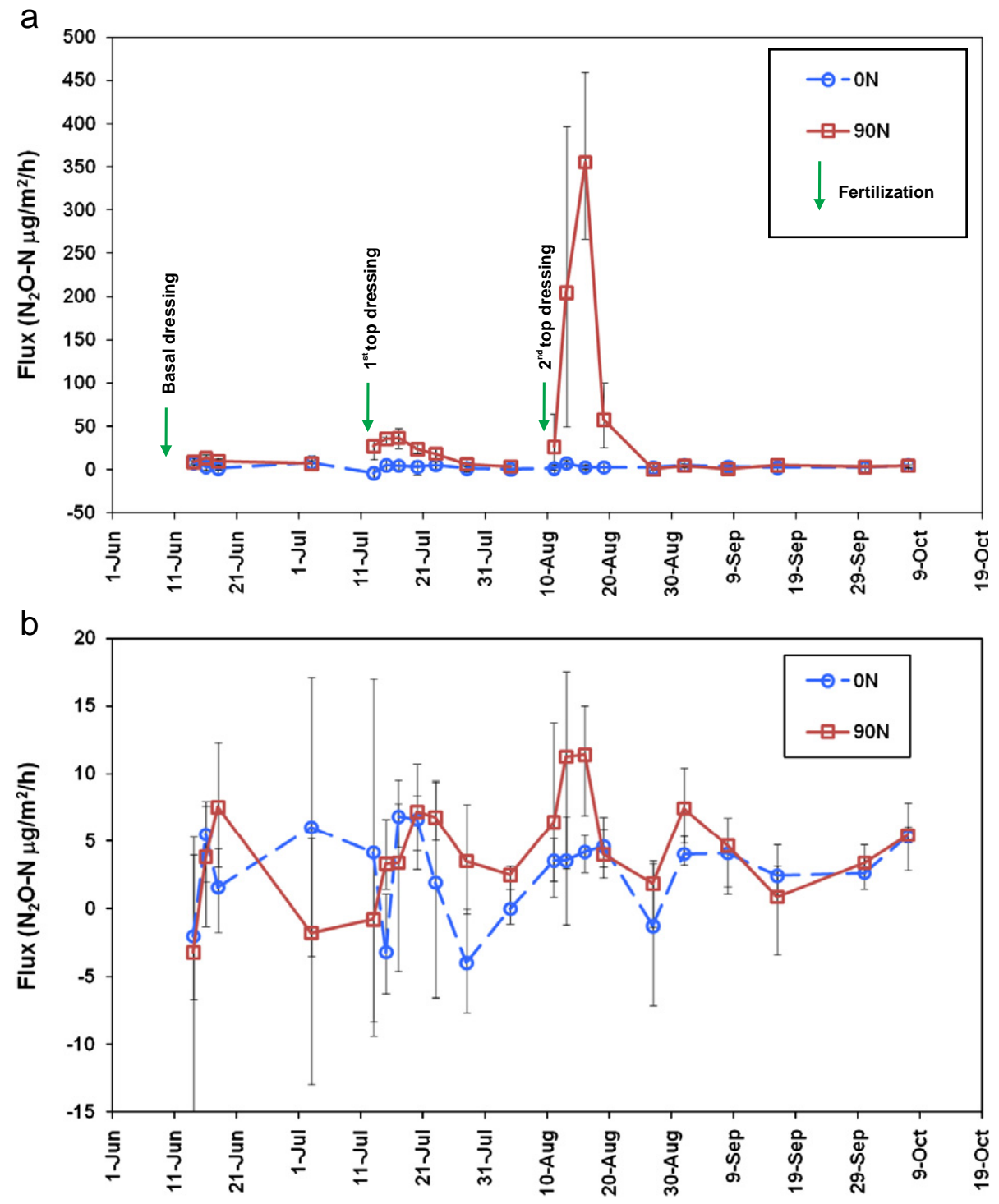

Fig. 2. Changes in $\mathrm{N}_{2} \mathrm{O}$ emissions from (a) ridges (b) furrows on Vertisol field cultivated with sweet sorghum. The vertical bars show the range of the flux in triplicate measurements. $0 \mathrm{~N}$ : represents $\mathrm{N}_{2} \mathrm{O}$ emissions from plots with no nitrogen application; $90 \mathrm{~N}$ : represents $\mathrm{N}_{2} \mathrm{O}$ emissions from plots fertilized with $90 \mathrm{~kg} \mathrm{~N} / \mathrm{ha}$.

was $1.81 \mathrm{~N}_{2} \mathrm{O}-\mathrm{N} \mathrm{kg}$ /ha for $90 \mathrm{~N}$ treatment and $0.15 \mathrm{~N}_{2} \mathrm{O}-\mathrm{N} \mathrm{kg} /$ ha for $0 \mathrm{~N}$ treatment.

\subsection{Variation in $\mathrm{N}_{2} \mathrm{O}-\mathrm{N}$ emissions between Vertisols and Alfisols}

The difference in $\mathrm{N}_{2} \mathrm{O}$ emissions between these two soils provides evidence that $\mathrm{N}_{2} \mathrm{O}$ emissions from fertilizers are significantly influenced by interactions with other factors such as the soil physical and chemical properties. The underlying causes of higher $\mathrm{N}_{2} \mathrm{O}$ fluxes from Alfisols when compared to the Vertisols might be attributed to the differences in the soil characteristics such as organic $\mathrm{C}$ and nitrogen pools, waterholding capacity, $\mathrm{pH}$, texture and microbial community structure. In the current study, the initial total $\mathrm{N}$ in Alfisols and Vertisols was 760 and $560 \mathrm{mg} / \mathrm{kg}$ soil, respectively. This suggests that the higher soil total $\mathrm{N}$ in Alfisols might have provided adequate amounts of $\mathrm{NO}_{3}^{-}$and $\mathrm{NH}_{4}^{+}$to the substrate pool following $\mathrm{N}$ mineralization. A negative nonlinear relationship between $\mathrm{N}_{2} \mathrm{O}$ emissions and soil organic $\mathrm{C}$, suggests that agricultural soils with higher organic $\mathrm{C}$ yield lower $\mathrm{N}_{2} \mathrm{O}$ emissions (Huang et al. 2002). Huang et al. (2002) proposed that the higher $C$ in soils would positively influence the reduction of $\mathrm{N}_{2} \mathrm{O}$ to $\mathrm{N}_{2}$ in consequence of a higher content of electron donors. The organic $\mathrm{C}$ content of the two soils in this study (Table 1), was slightly different and that also could be one of the factors for the lower $\mathrm{N}_{2} \mathrm{O}$ emissions from Vertisols than Alfisols. Generally Vertisols have higher clay content, poorly drained and have a low hydraulic conductivity, while Alfisols are sandy loam to sandy clay loam in texture, and the soils are moderately to well-drained with reasonable hydraulic conductivity. High $\mathrm{N}_{2} \mathrm{O} /\left(\mathrm{N}_{2} \mathrm{O}+\mathrm{N}_{2}\right)$ ratios are the characteristic of fairly well-aerated soils, in which $\mathrm{N}_{2} \mathrm{O}$ can easily diffuse away, and thus is not further reduced to $\mathrm{N}_{2}$ by denitrifying organisms (Webster and Hopkins, 1996). In the case of Vertisols, the poor drainage of these soils may limit gas diffusion, thus, the $\mathrm{N}_{2} \mathrm{O}$ formed following nitrification and denitrification processes in the saturated soil moisture regime might have been reduced to $\mathrm{N}_{2}$ before it could escape to the soil-air interface. Further, the activity of $\mathrm{N}_{2} \mathrm{O}$ reductase enzyme is generally thought to increase with increasing $\mathrm{pH}$ values (Chapuis-Lardy et al., 2007). Thus, the high $\mathrm{pH}$ of the Vertisols (8.3) might have increased the activity of $\mathrm{N}_{2} \mathrm{O}$ reductase enzyme, resulting in lower $\mathrm{N}_{2} \mathrm{O}$ emissions. Li et al. (1992) and Velthof et al. (2002) reported that an increase in clay content decreased $\mathrm{N}_{2} \mathrm{O}$ emissions because of the effect of clay on the soil hydraulic properties. The results of this study may suggest that somewhat poorly aerated soils under fertilizer $\mathrm{N}$ application may emit less of the applied $\mathrm{N}$ as $\mathrm{N}_{2} \mathrm{O}$ than well-aerated soils. 

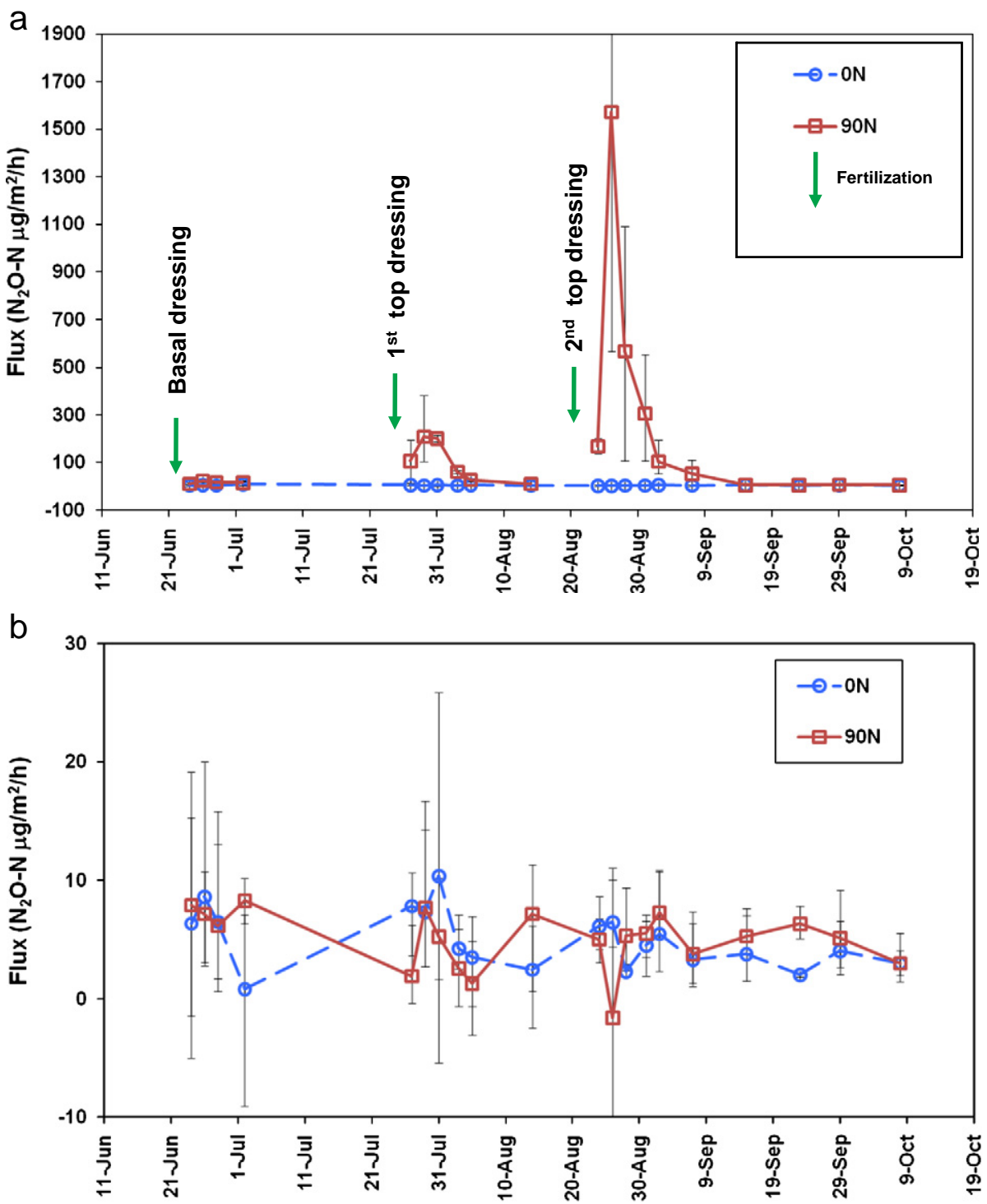

Fig. 3. Changes in $\mathrm{N}_{2} \mathrm{O}$ emissions from (a) ridges (b) furrows on Alfisol field cultivated with sweet sorghum. The vertical bars show the range of the flux in triplicate measurements. $0 \mathrm{~N}$ : represents $\mathrm{N}_{2} \mathrm{O}$ emissions from plots with no nitrogen application; $90 \mathrm{~N}$ : represents $\mathrm{N}_{2} \mathrm{O}$ emissions from plots fertilized with $90 \mathrm{~kg} \mathrm{~N} / \mathrm{ha}$.

Table 2

Cumulative $\mathrm{N}_{2} \mathrm{O}$ fluxes $\left(\mathrm{N}_{2} \mathrm{O}-\mathrm{N} \mathrm{kg} / \mathrm{ha}\right)$ (mean $\pm \mathrm{SD}$ ) from Alfisols and Vertisols during sweet sorghum cultivation.

\begin{tabular}{lllr}
\hline $\mathrm{N}$ treatment & Position & \multicolumn{2}{l}{ Field } \\
\cline { 3 - 4 } & & Alfisol & \multicolumn{1}{c}{ Vertisol } \\
\hline $0 \mathrm{~N}$ & Ridge & $0.15 \pm 0.05$ & $0.09 \pm 0.02$ \\
& Furrow & $0.11 \pm 0.05$ & $0.075 \pm 0.06$ \\
$90 \mathrm{~N}$ & Ridge & $1.81 \pm 0.75$ & $0.70 \pm 0.23$ \\
& Furrow & $0.16 \pm 0.02$ & $0.10 \pm 0.03$ \\
ANOVA & & & \\
$\mathrm{F}$ & & $* *$ & \\
$\mathrm{~N}$ & & $* * *$ & \\
$\mathrm{~N} \times \mathrm{F}$ & & $* *$ & \\
$\mathrm{P}$ & & $* * *$ & \\
$\mathrm{P} \times \mathrm{F}$ & & $* * *$ & \\
$\mathrm{P} \times \mathrm{N}$ & & $* *$ & \\
$\mathrm{P} \times \mathrm{F} \times \mathrm{N}$ & & & \\
\hline
\end{tabular}

F: Field; R: Replication; N: N treatment; P: Position.

$*_{* * *}^{* *}$ Significant at 0.01 probability level.

** Significant at 0.05 probability level.

\subsection{Loss of applied nitrogen as $\mathrm{N}_{2} \mathrm{O}$}

For calculation of emission factors of $\mathrm{N}_{2} \mathrm{O}$, the $\mathrm{N}_{2} \mathrm{O}$ emissions measured from the ridges only were taken into account. Further, it was assumed that the $\mathrm{N}_{2} \mathrm{O}$ flux measured at the time of sampling represented the average flux of the measured day. On the days when gas sampling was not conducted, the $\mathrm{N}_{2} \mathrm{O}$ fluxes were calculated by linear interpolation between sampling occasions. For periods before the fertilizer application when measurements were not made, the background $\mathrm{N}_{2} \mathrm{O}$ flux values were substituted. Based on these assumptions, the $\mathrm{N}_{2} \mathrm{O}-\mathrm{N}$ emission was integrated for the entire experimental period.

The emission factor for $\mathrm{N}_{2} \mathrm{O}$ was calculated based on the definition by Intergovernmental Panel on Climate Change (IPCC) (2006):

$\mathrm{EF}=(\mathrm{E}-\mathrm{Eo}) / \mathrm{N} \times 100$

where $\mathrm{E}$ and Eo are $\mathrm{N}_{2} \mathrm{O}$ emission from plots with and without $\mathrm{N}$ fertilizer application, respectively. $\mathrm{N}$ is the total amount of $\mathrm{N}$ application over the entire growing season. From the calculations, it was found that $0.90 \%$ of the applied $\mathrm{N}$ was lost as $\mathrm{N}_{2} \mathrm{O}$ from Alfisols, and $0.32 \%$ 
of the applied $\mathrm{N}$ was lost from Vertisols. The emission factors for $\mathrm{N}_{2} \mathrm{O}$ are in broad agreement with the values reported in the literature. For example, Hellebrand et al. (2008) found the mean direct fertilizerinduced emissions during energy crop cultivation on loamy sand soils to be between 0.30 and $0.40 \%$. Pathak et al. (2002) reported that $0.38 \%$ of applied $\mathrm{N}$ was lost as $\mathrm{N}_{2} \mathrm{O}$ from the rice-wheat systems of the Indo-Gangetic plains of India. However, the proportion of $\mathrm{N}$ fertilizer applied that was lost as $\mathrm{N}_{2} \mathrm{O}$ from canola crop in a semi-arid region of south-western Australia was only 0.06\% (Barton et al., 2010).

The current emission factor approach using the IPCC methodology may not reflect the complex processes controlling soil $\mathrm{N}_{2} \mathrm{O}$ flux. According to the IPCC default emission factor, $1.25 \%$ of fertilizer $\mathrm{N}$ is emitted as $\mathrm{N}_{2} \mathrm{O}$. This study reveals the importance of employing regionally specific emission factors when assessing GHG emissions as there are distinct regional differences in $\mathrm{N}_{2} \mathrm{O}$ emission factors.

\section{Conclusions}

To our knowledge this is the first report on $\mathrm{N}_{2} \mathrm{O}$ emissions from agricultural soils in this semi-arid region. It was found that $0.90 \%$ of the applied nitrogen was lost as $\mathrm{N}_{2} \mathrm{O}$ from Alfisols and $0.32 \%$ of the applied nitrogen was lost from Vertisols. Our results suggest that $\mathrm{N}_{2} \mathrm{O}$ emissions are greatly dependent on the soil properties. Although, the weather conditions were identical and similar agricultural management practices were followed for sweet sorghum cultivation in Alfisols and Vertisols, the emissions of $\mathrm{N}_{2} \mathrm{O}$ were different in these two soil types. Therefore, the monitoring of $\mathrm{N}_{2} \mathrm{O}$ emissions from different agroecological regions, having different soil types, rainfall characteristics, cropping systems and crop management practices are necessary to develop comprehensive and accurate GHG inventories.

\section{Acknowledgments}

This study was a part of a research project "Development of sustainable soil fertility management for sorghum and sweet sorghum through effective use of biological nitrification inhibition (BNI)" funded by grants from the Ministry of Agriculture, Forestry and Fisheries, Japan. The authors would like to thank Dr. Shigeto Sudo of the National Institute for Agro-Environmental Sciences, Japan for giving valuable suggestions and providing $\mathrm{N}_{2} \mathrm{O}$ gas standards.

\section{References}

Agoramoorthy G. India's biofuel development: swings and roundabouts. Environ Sci Technol 2012;46:589-90.

Barton L, Kiese R, Gatter D, Butterbach-Bahl K, Buck R, Hinz C, et al. Nitrous oxide emissions from a cropped soil in a semi-arid climate. Glob Change Biol 2008;14:177-92.
Barton L, Murphy DV, Kiese R, Butterbach-Bahl K. Soil nitrous oxide and methane fluxes are low from a bioenergy crop (canola) grown in a semi-arid climate. Globa Change Biol Bioenergy 2010;2:1-15.

Chapuis-Lardy L, Wrage N, Metay A, Chotte JL, Bernoux M. Soils, a sink for $\mathrm{N}_{2} \mathrm{O}$ ? A review. Global Change Biol 2007;13:1-17.

Freney JR. Emission of nitrous oxide from soils used for agriculture. Nutr Cycl Agroecosyst 1997;49:1-6.

Fernández-Luqueño F, Reyes-Varela V, Martínez-Suárez C, Reynoso-Keller RE, Méndez-Bautista J, Ruiz-Romero E, et al. Emission of $\mathrm{CO}_{2}$ and $\mathrm{N}_{2} \mathrm{O}$ from soil cultivated with common bean (Phaseolus vulgaris L.) fertilized with different $\mathrm{N}$ sources. Sci Total Environ 2009;407:4289-96.

Hellebrand HJ, Scholz V, Jürgen K. Fertilizer induced nitrous oxide emissions during energy crop cultivation on loamy sand soils. Atmos Environ 2008;42:8403-11.

Huang Y, Jiao Y, Zong L, Wang Y, Sass RL. Nitrous oxide emissions from the wheatgrowing season in eighteen Chinese paddy soils: an outdoor pot experiment. Biol Fertil Soils 2002;36:411-7.

Intergovernmental Panel on Climate Change (IPCC). Volume 4 Agriculture, Forestry and Other Land Use. In: Eggleston HS, Buendia L, Miwa K, Ngara T, Tanabe K, editors. 2006 IPCC Guidelines for National Greenhouse Gas Inventories, Prepared by the National Greenhouse Gas Inventories Programme. IGES, Japan; 2006.

Intergovernmental Panel on Climate Change (IPCC). Climate change. In: Synthesis report of the fourth assessment report of IPCC; 2007.

Kroeze C, Mosier A, Bouwman L. Closing the global $\mathrm{N}_{2} \mathrm{O}$ budget: a retrospective analysis 1500-1994. Global Biogeochem Cycles 1999;13:1-8.

Li CS, Frolking S, Frolking TA. A model of nitrous-oxide evolution from soil driven by rainfall events. 1. Model structure and sensitivity. J Geophys Res 1992;97:9759-76.

McIntosh M. Analysis of combined experiments. J Agron 1983;75:153-5.

McTaggart IP, Smith KA. Nitrous oxide emission from arable and grassland soils: effect of crop type and nitrification inhibitors. Abstracts of 9th Nitrogen Workshop Braunschweig; 1996. p. 523-6. September.

Mosier A, Kroeze C, Navison C, Oenema O, Seitzinger S, van Cleemput O. Closing the atmospheric $\mathrm{N}_{2} \mathrm{O}$ budget: nitrous oxide emissions through the agricultural nitrogen cycle. Nutr Cycl Agroecosyst 1998;52:225-48.

Mosier A, Kroeze C. Potential impact on the global atmospheric $\mathrm{N}_{2} \mathrm{O}$ budget of the increased nitrogen input required to meet future global food demands. ChemosphereGlobal Change Sci 2000;2:465-73.

Pathak H, Bhatia A, Prasad S, Singh S, Kumar S, Jain MC, et al. Emission of nitrous oxide from rice-wheat systems of Indo-Gangetic plains of India. Environ Monit Assess 2002;77:163-78.

Pang J, Wang X, Mu Y, Ouyang Z, Liu W. Nitrous oxide emissions from an apple orchard soil in the semiarid Loess Plateau of China. Biol Fertil Soils 2009;46:37-44.

Parkin TB, Kaspar TC. Nitrous oxide emissions from corn-soybean systems in the Midwest. J Environ Qual 2006;35:1496-506.

Prasad R. Fertilizers and manures. Curr Sci 2012;102:894-8.

Rao PS, Rao SS, Seetharama N, Umakanth AV, Sanjana Reddy P, Reddy BVS, et al. Sweet sorghum for biofuel and strategies for its improvement. International Crops Research Institute for the Semi-Arid Tropics, India. Inf Bull 2009;No 77. 80 pp.

Sahrawat KL. Effects of temperature and moisture on urease activity in semi-arid tropical soil. Plant Soil 1984;78:401-8.

Sahrawat KL, Keeney DR. Nitrous oxide emission from soils. Adv Soil Sci 1986;4: 103-48.

Velthof GL, Kuikman PJ, Oenema O. Nitrous oxide emission from soils amended with crop residues. Nutr Cycl Agroecosyst 2002;62:249-61.

Watanabe T, Chairoj P, Tsuruta H, Masarngsan W, Wongwiwatchai C, Wonprasaid S, et al. Nitrous oxide emissions from fertilized upland fields in Thailand. Nutr Cycl Agroecosyst 2000;57:55-65.

Webster EA, Hopkins DW. Contributions from different microbial process to $\mathrm{N}_{2} \mathrm{O}$ emission from soil under different moisture regimes. Biol Fertil Soils 1996;22:331-5. 